\title{
Isolation and identification of restriction endonuclease SseBI
}

\author{
M.Rina ${ }^{1}$, M.Tzanodaskalaki ${ }^{1}$, A.Karagouni ${ }^{3}$, M.Pagomenou ${ }^{1}$ and V.Bouriotis ${ }^{1,2 \star}$ \\ ${ }^{1}$ Institute of Molecular Biology and Biotechnology, Enzyme Technology Division, PO Box 1515, \\ Heraklion 71110, Crete, ${ }^{2}$ University of Crete, Department of Biology, Division of Applied Biology and \\ Biotechnology, PO Box 1470, Heraklion 71110, Crete and ${ }^{3}$ Institute of General Botany, University of \\ Athens, Athens 15784, Greece
}

Submitted February 25, 1992

SseBI, an isoschizomer of StuI (1) has been purified from Streptomyces species. SseBI recognises the sequence $5^{\prime}$... AGGCCT ... 3' and cleaves between $G$ and $C$. The enzyme was purified using the following chromatographic steps: 1. Blue Sepharose F3GA, 2. Heparin-Sepharose.

The enzyme was free of contaminating nuclease activity. After 100 fold overdigestion on lambda DNA greater than $95 \%$ of the DNA fragments can be ligated and greater than $95 \%$ can be recut by SseBI. Optimal conditions for enzyme activity are $100 \mathrm{mM}$ $\mathrm{NaCl}, 50 \mathrm{mM}$ Tris $-\mathrm{HCl}$ (pH 7.9), $10 \mathrm{mM} \mathrm{MgCl}_{2}, 1 \mathrm{mM}$ dithiothreitol at $37^{\circ} \mathrm{C}$.

The fragments produced by digestion of lambda DNA, Adeno 2 , pBR322, $\Phi$ X174 and SV-40 match those predicted by cleavage at the sequence AGGCCT (Figure 1, lanes 4-8). In order to determine the cleavage site within the recognition sequence, the vector $\Phi$ X174 which contained a recognition site for the enzyme was digested by the enzyme then annealed with forward or reverse sequencing primers and extended with Klenow enzyme in the presence of $\alpha^{32} \mathrm{P}-\mathrm{dATP}$. Dideoxy sequencing reactions were performed at this region with the same primers and run in parallel with the extended products (2).

Results in Figure 2 show that the extended products of the forward (lane F) and the reverse (lane $R$ ) sequencing primers comigrate with the band corresponding to the $3^{\prime} \mathrm{G}$ in the $5^{\prime} \ldots$ AGGCCT ... 3' sequence. Therefore SseBI recognises and cleaves the following sequence:

$$
\begin{aligned}
& \text { 5' ... AGGICCT ... 3' } \\
& 3^{\prime} \text {... TCCIGGA ... 5' }
\end{aligned}
$$

\section{REFERENCES}

1. Shimotsu,H., Takahashi,H. and Salto,H. (1980) Gene 11, 219-225.

2. Tabor,S. and Richardson,C.C. (1987) Proc. Natl. Acad. Sci. USA 84, 4767-4771.

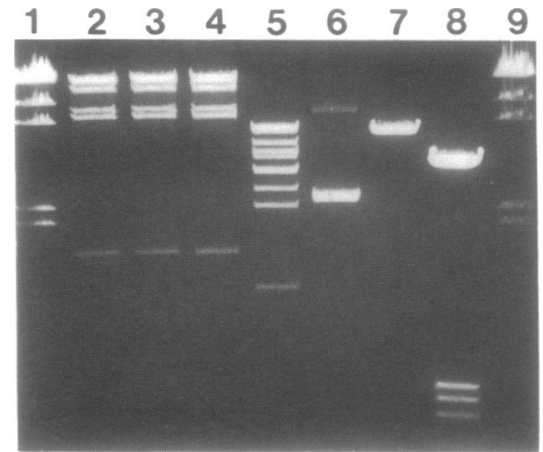

Figure 1. SseBI digests: lane 2: lambda DNA digested by StuI, 3: lambda DNA digested by StuI and SseBI, 4: lambda DNA, 5: Adeno-2, 6: pBR322, 7: $\Phi$ X174 8: SV40, lanes 1,9: lambda-HindIII size standard.

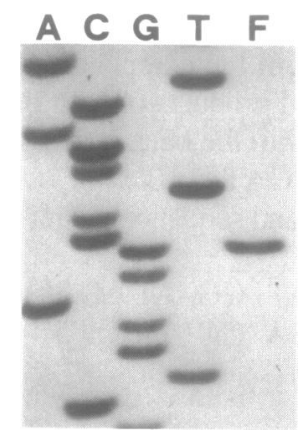

Figure 2. 